\title{
O Efeito do Título de Propriedade da Terra na Determinação da Renda Rural
}

\author{
Ricardo Luis Chaves Feijó ${ }^{1}$
}

Resumo: $\mathrm{O}$ artigo utiliza a análise neoinstitucional no intuito de respaldar a expectativa de que mudanças na estrutura de direitos de propriedade advindas com a reforma agrária no Brasil, em anos recentes, possam afetar a formação da renda nos estabelecimentos rurais. Tenta-se captar empiricamente esse efeito examinando as bases das PNADs em diferentes anos.

Palavras-chaves: Titularidade da terra, reforma agrária, PNAD, economia neoinstitucional.

Abstract: The article uses the neoinstitutional analysis in order to support expectations that the changes in the structure of property rights related to land reform in Brazil, in recent years, might affect the composition of revenue in rural establishments. Therefore, we attempt to empirically capture this impact, examining the PNADs databases in different years.

Key-words: Land title, land reform, PNAD, neoinstitutional economics.

Classificação JEL: Q15.

1 Professor Associado da Faculdade de Economia, Administração e Contabilidade de Ribeirão Preto (Universidade de São Paulo). E-mail:riccfeij@usp.br 


\section{Introdução}

Pretende-se examinar se, no âmbito dos estabelecimentos rurais, a concessão de direitos de propriedade no campo, por meio da reforma agrária, acarreta benefícios produtivos. Investiga-se a possibilidade de aferir-se algum resultado da reforma agrária em uma análise econômica a posteriori. Reforma agrária implica em assentamentos rurais. O assentado passa a ter posse e direitos especiais sobre a terra. Mesmo quando um título de propriedade lhe é entregue, tal título não configura um pleno direito de propriedade, pois as regras do programa impõem limitações ao usufruto e à disposição da terra. Por exemplo, não pode agredir o meio ambiente, não pode revender a terra, deve desenvolver a aptidão agrícola, deve residir na propriedade etc. Em todo caso, o que está envolvido no processo é a concessão de título de propriedade, a mudança na estrutura dos direitos de propriedade no campo. E, nesse ponto, a chamada Economia Neoinstitucional tem muito a oferecer no intuito de interpretar, teórica e empiricamente, o processo em curso. O impacto dos direitos de propriedade na produção e na renda rurais é um tema ainda recente na literatura especializada. O tipo de estudo mais frequente focaliza os resultados sociais da reforma agrária, como ela afeta a distribuição da renda no campo, os indicadores sociais etc. Mas não é essa a questão que se pretende investigar neste estudo: não é o impacto social da reforma agrária, mas os efeitos da titulação fundiária no desempenho do estabelecimento rural, mesmo que previamente o homem do campo já tenha a posse informal da terra. Há duas análises distintas que iluminam e se complementam no estudo do impacto econômico (microeconômico) da reforma agrária: (1) Saber quem é mais produtivo, se o proprietário ou o não proprietário, ou então, qual dos dois grupos apresenta a maior renda média. Este tipo de análise encobre muitas outras dimensões do processo de formação da renda agrícola, de modo que, simplesmente comparar o desempenho de dois grupos, em termos de médias, não explica muita coisa. (2) Saber qual o impacto produtivo quando se concede o título de proprietário da terra ao agente que anteriormente não tinha vínculo formal com a terra, ou então que tinha direitos estabelecidos em bases precárias (enforcement privado etc.).

Como isolar o efeito da propriedade na formação da renda? Usando a PNAD (Pesquisa Nacional por Amostra de Domicílios), pensa-se em identificar o efeito da variável "proprietário" de uma maneira singela por meio de equações de rendimento análogas às que foram utilizadas por Hoffmann e Ney (2003), mas com a inclusão dessa variável. Observando-se a variação no R2 ajustado, pode-se aferir o efeito da variável adicionada na qualidade da regressão. O propósito é o de utilizar esse método aplicando-o a PNADs em diferentes anos 
selecionados e acompanhar, inclusive, a variação nos coeficientes da regressão ao longo desses anos. Então, o propósito destas iniciativas em testes econométricos é o de medir o papel da variável de propriedade na formação dos rendimentos agrícolas. Estes procedimentos contemplam, na verdade, as duas estratégias de análise apontadas anteriormente: esclarecem a questão (1) de saber qual dos grupos é mais produtivo e também a abordagem (2), que se preocupa em investigar se a concessão de titularidade da terra afeta ou não o desempenho produtivo. Mais adequado do que simplesmente comparar médias, o modelo de regressão com muitas variáveis explicativas permite avaliar o papel da variável proprietário na formação da renda, ou seja, possibilita fazer algum tipo de avaliação do efeito dos assentamentos na geração da renda rural. Podese, por exemplo, acompanhar a evolução dos coeficientes da variável proprietário em diferentes anos.

Este artigo organiza-se em nove seções, incluindo-se esta e a parte conclusiva. Na seção 2, apresenta-se a teoria neoinstitucional dos direitos de propriedade; na seção 3, esboça-se o impacto econômico esperado do processo de reforma agrária à luz da Economia Neoinstitucional. Na seção 4, argumentase de que forma o uso das informações das PNADs pode confirmar alguns resultados teóricos da Economia Neoinstitucional. Nas seções 5 a 8, faz-se a exposição de dados e alguns cálculos estatísticos.

\section{A teoria microeconômica dos direitos de propriedade}

Direitos sobre a terra rural na forma de título de propriedade devem presumidamente afetar o resultado econômico. No entanto, para demonstrá-lo é necessário expandir a ferramenta analítica da microeconomia no intuito de tornar endógena a variável do direito de propriedade e, desta forma, condicionar os principais resultados advindos de seus teoremas. A microeconomia neoclássica tradicional não o faz. No entanto, tem-se hoje toda uma literatura econômica que trata dos direitos de propriedade sem abdicar do núcleo rígido do programa de pesquisa neoclássico, literatura esta intitulada Economia Neoinstitucional.

Basicamente trata-se de explicar o comportamento dos agentes e os resultados econômicos sem abdicar da hipótese de escolha racional e comportamento maximizador deles ${ }^{2}$. O que se procura é incorporar as ideias

2 Fazem parte desta escola autores como Louis de Alessi, Armen A. Alchian, Harold Demsetz e Guido Calabresi, considerados os principais autores da Economia Neoinstitucional. Cabe ainda destacar as contribuições de Robert Paul Thomas, R. C. O. Matthews, John J. 


\section{6 - 0 Efeito do Título de Propriedade da Terra na Determinação da Renda Rural}

de informação imperfeita, custo de transação, papel das instituições nas relações econômicas, e outras considerações no terreno da economia neoclássica, de modo a ampliar e generalizar o alcance de sua análise. Encontra-se, nesta literatura, uma maneira elegante de tratar teoricamente os direitos de propriedade nos resultados do processo econômico. Direito de propriedade tratase de instituição, regra social de comportamento, algo que afeta a conduta econômica dos agentes, e também que determina os resultados do processo produtivo. De fato, os resultados econômicos da produção dependem das regras sociais que condicionam a atividade. Em especial, focaliza-se o efeito da instituição dos direitos de propriedade.

A nova abordagem considera explicitamente o papel das regras e das especificidades dos contratos na hora de modelar teoricamente o processo econômico. A abordagem incorpora o fato de a informação ser incompleta e de ser obtida apenas a certo custo, bem como examina as consequências do conceito de custo de transação no resultado econômico. Diferentes estruturas sociais produzem diferentes resultados econômicos. Em especial, diferentes especificações de direitos de propriedade levam a consequências distintas. Mantendo-se a mesma lógica neoclássica, reconhece-se agora que a estrutura da organização econômica e os decorrentes custos de transação têm profundas implicações na alocação de recursos.

A economia neoclássica tradicional estuda e identifica as propriedades de um sistema de livre mercado. O conhecido Teorema de Coase assevera que a hipótese de informação plena leva à alocação ótima. Esse teorema, porém, não é válido no modelo com informação incompleta. Quando a informação é escassa, a distribuição inicial dos direitos de propriedade afeta o resultado econômico: a solução de ótimo alocativo não é atingida, e a proximidade maior ou menor do ponto de eficiência depende da distribuição dos direitos de propriedade entre os agentes. Então, os direitos de propriedade são explicitamente incorporados no modelo econômico quando se considera informação incompleta. Neste caso, eles passam a afetar o resultado. Confeccionar contratos em trocas voluntárias torna-se então um problema. Os contratos têm custos. Surgem custos explícitos de mensuração dos atributos qualitativos da mercadoria (as diversas qualidades marginais), custos de aferição das dotações pessoais e do comportamento da outra parte envolvida, custos quanto à imposição da disciplina do contrato (enforcement) e vários outros tipos de custos que não existiriam se a informação fosse plena.

Uma das proposições centrais da Economia Neoinstitucional é a de que os custos de transação influenciam sistematicamente a estrutura dos contratos, da organização dos mercados e das instituições econômicas em geral. Quando 
os custos de transação se elevam, as forças econômicas, na competição, trabalham na direção de novos arranjos que procuram reduzir tais custos. Examina-se, então, o que define os tais direitos de propriedade, para depois passar à exposição mais específica dos direitos fundiários. Direitos de propriedade são os direitos dos indivíduos de utilizar recursos ${ }^{3}$. Alchian (1965) enfatiza que os direitos de propriedade, na concepção econômica, não se limitam à dimensão legal, pois, além dela, inclui também a questão das normas sociais; ou seja, a força da etiqueta, dos costumes sociais, da ameaça do ostracismo etc., também condiciona o uso dos recursos e, assim, circunscreve os direitos de propriedade. Os direitos de propriedade não são exercidos sem nenhum custo. Pelo contrário, eles envolvem custos sociais consideráveis. A observância desses direitos implica em excluir outros do usufruto de recursos escassos pertencentes a proprietários. Há sempre um custo envolvido, não apenas o custo de imposição (enforcement) dos direitos de propriedade, mas os de mensuração e de definição dos ativos em questão.

Direitos de propriedade podem ser exercidos por indivíduos ou por uma coletividade (propriedade comunal). Neste último caso, uma comunidade controla o acesso ao recurso excluindo forasteiros e regulando o uso dele entre os que estão autorizados. As normas legais e sociais frequentemente estabelecem direitos de propriedade parcionados (partitioned). O exemplo da propriedade da terra rural ilustra bem esse princípio: ao mesmo tempo, muitos indivíduos podem possuir alguma porção de direitos no uso da terra. O Teorema de Coase, aplicado a esses casos, não seria válido, dada a presença de custos de transação. Quando se introduz custos deste tipo na análise, a alocação final dos recursos e o grau de eficiência alocativa alcançado dependem da partição inicial dos direitos de propriedade.

Numa transação econômica, as partes se vinculam por meio de contratos. Os contratos possuem um número de dimensões que determinam uma estrutura. Quando os direitos sobre um ativo são negociados, os contratos devem estipular as multiplas dimensões desse direito. Mas não se estipulam sempre todas as dimensões, porque isso envolve um custo, de modo que a análise racional custo-benefício marginal entra novamente em cena. Na situação em que os custos dos contatos são elevados, muitas das dimensões dos direitos de

Wallis, Mike Staten, John Umbeck, Steven N. S. Cheung e Leif Johansen.

3 Um dado sistema de direitos de propriedade constitui um método para assinalar a pessoas específicas a autoridade para selecionar bens particulares para qualquer uso dentro de uma classe não proibida de usos. Coube a Steve Pejovich (1982) resgatar esta importante ideia (que já aparecia em autores clássicos como Karl Marx). Depois dele, o renascimento que se seguiu do enfoque econômico dos direitos de propriedade deve-se a três autores: Armen Alchian (1965), Guido Calabresi (1961) e Harold Demsetz (1964). Sobre definição 


\section{8 - 0 Efeito do Título de Propriedade da Terra na Determinação da Renda Rural}

propriedade do ativo podem não ser explicitamente incluídas na transação, tornando-se fonte posterior de disputa.

Qual seria o impacto sobre o bem-estar da sociedade de se estabelecer direitos de propriedade exclusivos? Há um caso clássico em que se estuda o impacto dos direitos de propriedade em termos de análise de bem-estar: as consequências econômicas do uso compartilhado de insumos e o efeito da imposição de direitos de propriedade individuais sobre esses insumos. O resultado do modelo é bem conhecido: a competição entre usuários de insumos comuns pode resultar na dissipação da sua renda potencial. Dissipação na renda do ativo comum é uma maneira técnica de dizer que ocorreu uma perda global de bem-estar. Também a produção é reduzida em relação ao que seria alcançado no regime de proprietário único do fator de produção. Neste caso com propriedade exclusiva, a contribuição da última porção de mão de obra empregada seria maior do que o custo de oportunidade ${ }^{4}$. A Economia Neoinstitucional demonstra que, no uso comum de fatores, a renda seria inteiramente dissipada antes mesmo que a condição de equilíbrio fosse alcançada.

Até aqui, a análise ainda não tratou dos custos explícitos de imposição e proteção dos direitos de propriedade. Há custos tanto para o Estado quanto para os indivíduos privados em estabelecer direitos exclusivos. Em geral, são consideráveis os custos dos recursos alocados não diretamente na produção, mas na imposição de direitos de propriedade. O nível desses custos depende da situação em análise e nem sempre o estado incorre para impor esses direitos em menos custo do que o setor privado ${ }^{5}$. Os custos de enforcement da propriedade são variáveis, se repetem a cada período de tempo, e são incorridos tanto pelo estado quanto pelos proprietários.

De modo geral, quando os custos de transação são elevados, a alocação dos recursos em uma economia de mercado é afetada significativamente pela estrutura de imputações de direitos de propriedade legais e pela eficiência no funcionamento do Estado e do poder judiciário. Os resultados econômicos das atividades organizadas pelas firmas dependem tanto das regras internas das firmas quanto da estrutura externa dos direitos de propriedade. Jensen e Meckling (1979) consideram uma função de produção que depende tanto da estrutura dos direitos de propriedade quanto do estado da tecnologia. Haveria, então, várias estruturas, ou regras externas do jogo da produção, cada qual associada a uma função de produção. Ou seja, só há uma única função de

dos direitos de propriedade, ver Alchian (1965, pp. 816-829).

4 Steven N. S. (1970) e Eggertsson (1999, p. 84-91). 
produção compatível com uma atribuição legal e social de direitos de propriedade, regras de contratos, regras de punição, poder policial etc. A firma impõe a seu modo as regras internas do jogo, que são as suas normas específicas de conduta aplicáveis a seus empregados. Então, a lição é que os direitos de propriedade afetam o desempenho produtivo ao condicionar a função de produção. Mas a relação não é mecânica e linear: depende da escolha de regras internas na organização da produção.

\section{Considerações teóricas relativas à reforma agrária}

A fim de simplificar a consideração teórica da reforma agrária, cabe identificar casos estilizados. Para tanto, assinala-se quatro situações possíveis em que ocorrem mudanças na estrutura dos direitos de propriedade da terra sob a égide do programa de reforma agrária no Brasil:

(1) O insumo terra é de uso comum. Pratica-se, então, algum tipo de atividade agropecuária em caráter itinerante; há um rodízio de agricultores, as terras não estão demarcadas e os lotes para plantações são arbitrariamente alocados entre os usuários. A reforma agrária, neste caso, visa estabelecer direitos de propriedade da terra onde nada havia. Migra-se do modelo de uso comum do insumo terra para o modelo de direitos de propriedade sobre ele. Este caso se aplica a algumas regiões da orla da fronteira agrícola e periferia da região amazônica.

(2) A terra é tida como propriedade particular, mas os direitos de propriedade não são legalmente reconhecidos. O lote em questão é ocupado por "grileiros" que utilizam a violência para expulsar indesejados, praticando-se, assim, um direito de propriedade de reconhecimento social, mas não legal, cujo custo de imposição e monitoramento é inteiramente privado. A reforma agrária, neste caso, vem redefinindo os direitos de propriedade e substituindo o custo de enforcement privado pela imposição pública de direitos agora legalmente reconhecidos. Verifica-se algo deste tipo na região sudeste do Pará, noroeste de Tocantins e regiões do Maranhão, entre outros lugares.

(3) A terra tem seus direitos de propriedade legalmente reconhecidos, mas há contestações. A norma legal não coincide completamente com a norma social. Os grupos organizados dos "sem-terra" questionam o embasamento legal desses direitos e argumentam que as terras são, 
na verdade, de domínio público e deveriam ser desapropriadas para efeito de novos assentamentos. Ocorre isto, por exemplo, na região paulista do Pontal do Paranapanema. Neste caso, à reforma agrária cumpre estabelecer direitos de propriedade reconhecidos socialmente, em caráter definitivo, em situações de precário amparo legal dos direitos ou em que não havia reconhecimento social.

(4) Situação na qual viceja o direito de propriedade da terra, mas a terra não cumpre a determinação legal de ser produtiva. A terra é de uso essencialmente especulativo, disfarçado muitas vezes por culturas esporádicas e um tipo de pecuária ultraextensiva. Situações assim disseminam-se pelo País, mas se verificam principalmente em regiões do Centro-Oeste, oeste baiano etc. A reforma agrária age, neste caso, no sentido de transferir os direitos de propriedade, alterando sua estrutura e redistribuindo-os entre indivíduos.

Nota-se que, na realidade, ocorrem situações híbridas que envolvem simultaneamente mais de um dos quatro casos padrão. Por exemplo, a reforma agrária na região do Pontal do Paranapanema envolve os casos (3) e (4) ao mesmo tempo.

Começando naturalmente pelo tipo (1) de reforma agrária: trata-se do caso clássico, já examinado teoricamente na seção anterior, quanto ao seu impacto no bem-estar social: o uso compartilhado do insumo terra é ineficiente, pois a competição entre usuários de insumos comuns acarreta a dissipação da sua renda potencial, ou seja, ocorre perda de bem-estar social. Cada agricultor, atuando na terra de uso comum, impõe aos demais um custo (por exemplo, com a degradação da terra). A sua decisão de plantar ignora os custos que ele impõe aos demais agricultores. Novos plantadores irão trabalhar no cultivo até o ponto em que o produto médio da unidade de trabalho prévia (inframarginal) iguala-se ao custo de oportunidade de se aplicar trabalho à terra. $\mathrm{O}$ excesso de agricultores reduz à zero a renda do recurso natural. O efeito da imposição de direitos de propriedade individuais sobre a terra consiste em alocar um determinado lote de terra para apenas um agricultor. Com isso, maximiza-se o excedente do produtor; o que vale dizer: o nível de bem-estar social é consideravelmente menor com propriedade comunal em relação ao caso em que está assegurado o direito de propriedade da terra. Quando não viceja a propriedade privada, a renda da terra é dissipada, a produção agrícola é reduzida.

Analisa-se agora a situação (2): a terra é propriedade particular, mas os direitos de propriedade não são legalmente reconhecidos. O custo de imposição 
do direito é arcado inteiramente pelo setor privado. A reforma agrária altera os direitos de propriedade e substitui o custo de enforcement privado pelo pagamento público das despesas de imposição de direitos de propriedade. Há um evidente ganho de eficiência quando o Estado assegura os direitos de propriedade da terra, por meio da reforma agrária, pela distribuição de títulos de propriedade a pessoas (não importa se "grileiros" ou "sem-terras"): o agricultor economiza recursos próprios, pois não necessita mais alocar parte dos recursos para fazer respeitar seus alegados direitos de propriedade. O Estado arca com os custos dos direitos e deixa o setor privado livre para se dedicar ao seu negócio, sem custos adicionais com a defesa da terra etc. Ademais, a estrutura dos direitos de propriedade afeta o leque de escolhas individuais que determinam o nível de produção, pois condiciona os custos de utilizar arranjos contratuais alternativos.

A reforma agrária, ao assegurar direitos de propriedade com baixo custo de enforcement, certamente tem alguma implicação no resultado econômico. A propriedade do ativo, e da terra em particular, por dois aspectos básicos, facilita negociações entre os agentes envolvidos no processo produtivo: contorna problemas de informação assimétrica para os contratos (moral hazard e seleção adversa) e minimiza o custo de transação (custos com mensuração, com coleta de informação, supervisão e monitoramento). Como os indivíduos que se envolvem em negociações detêm, cada qual, informação privada não revelada e efetuam ações difíceis de serem monitoradas, a eficiência dos arranjos contratuais entre os agricultores (envolvendo cooperativas, fornecedores, clientes e bancos) dependerá da presença de instituições que funcionem como incentivos contra comportamentos oportunistas e desviantes.

A maneira em que direitos de propriedade facilitam as transações entre os produtores é explicada pela chamada Teoria da Agência. Nesta, argumentase que os contratos ancorados em garantias que incidem em direitos de propriedade oferecem um número maior de mecanismos que incentivam os agentes a realizar os esforços esperados e a revelar informações ${ }^{6}$. Na ótica da Economia Neoinstitucional, a falta de propriedade de ativos limita as oportunidades dos indivíduos de serem produtivos. Por outro lado, com o empenho contratual do título da propriedade, o consequente acesso a mercado, a contratos especiais e a um leque maior de transações deverá afetar a produtividade da firma. A existência dos direitos de propriedade da terra condiciona a escolha de tecnologias, a organização do trabalho e, com efeito, a eficiência alocativa. Indivíduos com pouca propriedade possuem capacidade limitada de realizar investimentos produtivos e de estabelecerem diversos tipos

5 Anderson e Hill (1983) e Eggertsson (1999, p. 96). 
de arranjos contratuais.

Quanto ao tipo (3) de reforma agrária, no qual a terra tem seus direitos de propriedade legalmente reconhecidos, mas há contestações, neste caso a norma legal não coincide completamente com a norma social. Caberia então à reforma agrária estabelecer direitos de propriedade reconhecidos não apenas legalmente, mas também socialmente. Não custa recordar a afirmação de Alchian de que os direitos de propriedade não se restringem à concepção legal de propriedade. Quanto maior o nível de contestação social dos direitos de propriedade legalmente reconhecido, maiores os custos de enforcement públicos e privados para se fazer prevalecer o respeito à propriedade. Situações de conflito social levam os proprietários a alocarem mais recursos na defesa do seu patrimônio, desviando-se recurso da produção, e isso deve implicar em ineficiência da produção. A reforma agrária, neste caso, consiste em assegurar, em certa região, um grau menor de contestação aos direitos de propriedade da terra. Ela poderá fazê-lo, por exemplo, não apenas assegurando os que já usufruem desse direito, mas distribuindo novos lotes em programas de assentamentos que permitam a convivência pacífica entre os novos e os antigos proprietários; agora na condição de que os direitos destes estarão reforçados no processo. É de se esperar ganhos de produtividade com essa modalidade de reforma agrária.

Finalmente, cabe examinar o último tipo de reforma agrária apontado: situação em que viceja o direito de propriedade da terra, mas a terra não cumpre a determinação legal de ser produtiva. Nesse caso, a reforma agrária transfere direitos de propriedade, redistribuindo-os entre indivíduos. Quase que por definição, é esperado, para este caso, que os novos assentados sejam mais produtivos que os antigos proprietários da terra, já que estes foram considerados improdutivos. Contudo, a análise deve ser mais ampla que isso e a questão pode ser atacada percorrendo toda a cadeia de efeitos gerais decorrentes deste processo. Mudanças na estrutura dos direitos de propriedade afetam o macrodesempenho de um sistema econômico por diversas maneiras. Primeiramente, esta cláusula da reforma agrária faz com que os proprietários atuais tenham que se preocupar com a produtividade de seus estabelecimentos mesmo que esse não seja o propósito deles. Ou seja, uma parte dos custos produtivos é, a bem da verdade, custos de enforcement dos direitos de propriedade disfarçados de custos produtivos. O propósito da produção passa a ser assegurar direitos de propriedade, a fim de que a mesma não seja considerada improdutiva e venha a ser desapropriada. Ora, se há um consenso social, cristalizado em lei, de que a terra deva ter uso produtivo, isto limita o direito de propriedade, 
e essa limitação trará consequências econômicas mais gerais. O próprio direito fica sub judice e os agentes passam a ter incerteza quando à segurança do direito. Isto limita a possibilidade de os proprietários firmarem certos contratos; aumenta o custo de transação, pois agora não basta ter em mãos o título da terra, mas algo que prove, a todo tempo, que a mesma tem desempenho produtivo mínimo.

\section{Uso das informações das PNADs na averiguação de resultados esperados}

Acredita-se que a inclusão da variável proprietário melhora o modelo linear de regressão com $n$ variáveis explicativas da formação da renda agrícola. O estudo padrão do qual parte esta pesquisa é o de Hoffmann e Ney (2003). A referência representa um avanço em relação a modelos anteriores que desconsideravam a contribuição de fatores associados à medida de riqueza. A área agrícola e a condição dos produtores (empregado, empregadores ou por conta própria) são consideradas, pelos autores, uma medida de riqueza. Estabelecimento com maior área implica, então, que o produtor dispõe de mais terras no processo produtivo; e, com base no efeito deste insumo, seria de se esperar que sua renda agrícola fosse mesmo maior. Modelos que desconsideram a área da propriedade tendem a superestimar o efeito da escolaridade na geração da renda rural, pois desconsideram a contribuição do insumo físico. Ou seja, a área do estabelecimento agrícola está correlacionada com o nível de educação do rural, de modo que a omissão da área superestima o coeficiente para a variável educação no modelo de regressão linear. A maior disponibilidade do insumo terra para alguns dos agentes significa que esses detêm maior volume de riqueza. Os estudos que só consideram a posição na ocupação como medida de riqueza são errôneos pelo fato de a posição na ocupação não refletir muito bem a riqueza dos indivíduos. O resultado do processo de formação de renda agrícola depende da condição do produtor. Para os empregadores e os que estão por conta própria, a área do estabelecimento é uma variável explicativa importante na formação da renda. Já para os empregados, a área não importa, pois a parcela da renda que pode ser imputada à área é absorvida pelo patrão e não entra no pagamento do salário, embora a área afete a produtividade do trabalho.

Hoffman e Ney optam por incorporar ao modelo de regressão, ao lado de outras variáveis explicativas, tanto a área (medida de riqueza) quanto a posição na ocupação (condição do produtor). Pensam em uma interação entre as duas 
variáveis: a condição de empregador e por conta própria faz a área afetar a renda agrícola. Mas há outro aspecto com que jogam os autores: a posição da ocupação acarreta um efeito de propriedade do capital físico (que eles denominam de posse da terra, não necessariamente a titularidade da mesma). A posse da terra deve ser entendida como a disponibilidade do insumo área para o trabalho na agricultura. Significa que mais fatores estarão associados ao trabalho agrícola, aumentando a produtividade deste, ou, então, ampliando a escala do trabalho, e com isso, possibilitando maiores rendimentos. Na avaliação dos autores citados, o fato de ser empregador ou por conta própria indica que o agente deva ser o proprietário do capital, e isso pode ter efeito na formação da renda agrícola.

Certamente deve haver maior correlação no meio rural entre ser empregador e ser proprietário, mais do que no meio urbano. Contudo, observamse muitos casos na agricultura de empregadores que não são proprietários da terra (são meros arrendatários capitalistas). A condição do produtor não é uma boa proxy para proprietário da terra. De qualquer modo, Hoffman e Ney não estão preocupados em medir o efeito da variável proprietário na estimação da renda agrícola; muito embora esta variável apareça nas bases das PNADs, ela nem é considerada no modelo de regressão desenvolvido por eles. $\mathrm{O}$ foco deles é outro: saber qual o impacto do uso de capital físico (notadamente terra) na formação da renda agrícola.

Não se nega que posição na ocupação e área sejam variáveis importantes no modelo de regressão para a determinação da renda. A posse de insumos (riqueza) leva a maiores rendimentos. Desconsiderar esse efeito superestima o impacto de fatores como educação na formação da renda, conforme bem apontado pelos dois autores. Entretanto, ao lado da posse, a propriedade da terra também contribui na formação dos rendimentos agrícolas.

Qual o efeito da elevação no número de proprietários rurais na determinação dos rendimentos agrícolas? Em todos os quatro tipos de reforma agrária analisados anteriormente espera-se que a renda agrícola dos recémproprietários aumente.

Empregar-se-á, na parte empírica deste estudo, o método de se comparar os coeficientes de regressão das variáveis explicativas entre diferentes anos, utilizando os dados da base da PNAD. A pesquisa avança em relação ao modelo do ensaio de Hoffmann e Ney (2003), não apenas porque serão comparados diferentes anos (eles só analisam a PNAD de 2001), mas também pelo fato de se incorporar a variável proprietário ("condição em relação ao empreendimento") como uma variável explicativa adicional no modelo de 
regressão linear.

Em relação à estatística descritiva, pensando na separação entre grupos de proprietários e de não proprietários, acredita-se que os assentamentos cumulativos da reforma agrária vêm diminuindo as diferenças de renda média entre os grupos de proprietários e de não proprietários. A incorporação de um novo proprietário no grupo dos produtores proprietários deve estar reduzindo a diferença de renda média entre os grupos, pois os recém- proprietários tendem a ter um desempenho inferior ao agricultor típico do grupo de proprietários: trata-se, em muitos casos, de pequenos agricultores pobres e sem possibilidades de auferirem muita renda no negócio, ao menos de início. Estes necessitam de ajuda de programas governamentais em financiamento, comercialização, assistência técnica etc.

Em média, o desempenho deles é bastante inferior ao dos tradicionais proprietários de terra. A renda média do grupo de proprietários obviamente diminui quando a margem, isto é, o rendimento do recém-admitido membro do grupo, for menor do que a média anterior do grupo. Por outro lado, acreditase que a renda média do grupo dos não proprietários esteja aumentando com a reforma agrária. A renda média do grupo de não proprietários aumenta, pois, se o antigo membro, agora expelido, apresenta um nível de renda agrícola inferior à média dos demais membros do grupo, a retirada dele do grupo faz com que a média do grupo dos não proprietários aumente com a reforma agrária. Então, este efeito de estreitamento entre os níveis de renda média dos dois grupos constitui um dos resultados empíricos que se espera constatar na estatística descritiva das PNADs na evolução dos anos.

Quanto ao modelo de regressão que se pensa aplicar à base da PNAD em diferentes anos, acompanhar-se-á a evolução do coeficiente da variável proprietário e sua contribuição marginal para a soma dos quadrados da regressão. Acredita-se que o coeficiente desta, ou sua contribuição para a estimativa da renda do estabelecimento rural, esteja diminuindo com o tempo, à medida que avança o processo de assentamento: é mais razoável imaginar que a variável proprietário esteja contribuindo mais para a estimativa da renda quando o grupo de proprietários apresenta famílias mais bem estabelecidas economicamente; a disseminação de assentamentos, ao reduzir a diferença de renda entre grupos, também reduz o impacto da variável explicativa dos direitos de propriedade na determinação da renda, pois a condição de ser ou não proprietário passa a estar menos correlacionada com o nível de renda. Vale dizer: a reforma agrária incrementa o número de proprietários pobres. Nota-se que a queda no impacto da variável "proprietário” na formação dos rendimentos 
agrícolas não contradiz o resultado teórico da Economia Neoinstitucional de que a concessão de direitos de propriedade contribui para viabilizar arranjos contratuais e sociais aos recém-assentados de modo a melhorar a condição de vida deles.

De fato, com a conquista do direito de propriedade, o agricultor tem todas as condições de passar a ter ganhos superiores. Mas isso é um efeito que deveria ser acompanhado individualmente para a mesma pessoa em diferentes amostras. Contudo, a PNAD não possibilita esse acompanhamento individual. O que se pretende demonstrar na parte empírica é o efeito do coeficiente na estimação da renda para todos os indivíduos da amostra, sem identificar e acompanhar cada qual. Nesse caso, o efeito esperado com o tempo é a redução do coeficiente ou da contribuição marginal da variável para a soma dos quadrados da regressão. Então, considera-se que observar as variações dos coeficientes da variável proprietário ao longo das PNADs é um excelente indicador da qualidade da reforma agrária, pois uma queda neste coeficiente, desde que ele seja significativo para a regressão, indica a intensidade e o efeito do processo de concessão de novos direitos de propriedade da terra.

Pode-se antecipar quais conclusões são esperadas na parte empírica do trabalho, embora os dados possam desapontar:

(1) Como acredita-se que os direitos de propriedade importam na formação dos rendimentos agrícolas, espera-se que a incorporação da variável "proprietário" melhore a regressão (medindo-se a qualidade dela e a intensidade da melhora pelo crescimento do R2 ajustado).

(2) Espera-se que, sob o impacto da reforma agrária, acentuada desde 1995, as diferenças na renda agrícola média entre os grupos de proprietários e de não proprietários estejam diminuindo com o tempo.

(3) Que os coeficientes de regressão da variável "proprietário" (e a contribuição marginal para a soma dos quadrados da regressão) decresçam ao longo dos anos, sendo menor nas PNADs mais recentes, enquanto indicativos da expansão de alcance do programa de reforma agrária.

\section{Comparando-se resultados empíricos com os da literatura}

Das variáveis disponibilizadas pela PNAD, interessa, para efeito desta pesquisa, um conjunto delimitado de variáveis que foram basicamente aquelas mesmas selecionadas no trabalho de Hoffmann e Ney (2003), e mais a variável V9021 sobre a condição do entrevistado em relação ao empreendimento agrícola: descreve 
o fato de ser proprietário ou outra condição (parceiro, arrendatário etc.). Regressões por mínimos quadrados que estimam a renda agrícola foram geradas no software estatístico SAS. Estima-se a contribuição marginal de cada fator para a soma dos quadrados dos resíduos para todos os anos das PNADs consideradas.

Para as equações de rendimento ajustadas pelo método dos mínimos quadrados, a variável dependente y é simplesmente o logaritmo neperiano do rendimento de todos os trabalhos das pessoas ocupadas. Grande parte das variáveis explicativas é binária: assume o valor 1 se a pessoa pertence a determinado grupo, ou zero, caso não pertença. São consideradas as seguintes variáveis binárias: uma para gênero e duas variáveis binárias para distinguir três posições na ocupação no trabalho principal. Assumem respectivamente o valor 1 para conta própria e empregador; a condição não representada, por exclusão, é a de empregado (tomado como base). Quatro binárias que assumem cada qual valor 1 para distinguir cor (etnia); branca não representada é a cor básica. Variável binária que diferencia a condição da pessoa na unidade familiar. Se for a pessoa de referência (arrimo), a binária assume o valor 1 e zero caso contrário (cônjuge, filho, pensionista, empregado doméstico etc.). Variável binária "proprietário": trata-se de um importante acréscimo da pesquisa, na medida em que se tenta captar o efeito dos direitos de propriedade na equação dos rendimentos. Utiliza-se a variável PNAD "condição em relação ao empreendimento agrícola”.

Além dessas binárias, algumas variáveis numéricas são incorporadas no modelo. São elas: escolaridade; a idade da pessoa medida em dezenas de anos (a idade é medida em dezenas de anos para evitar coeficientes muito pequenos); o quadrado da variável "idade", para captar a hipótese de que a renda não varie linearmente com a idade; o logaritmo do número de horas semanais de trabalho; uma variável destinada a captar o efeito da área do empreendimento. Toma-se o logaritmo da área, obtido por meio de um cálculo que elimina as observações de áreas muito pequenas ou muito grandes: os empregadores e por conta própria com área abaixo de 0,05 e acima de 10.000 hectares, seguindo sugestão da literatura.

Definida a base da PNAD rural e o procedimento para expansão da amostra, compara-se os resultados da regressão com o estudo de referência para a PNAD de 2001. Antes disso, nota-se que a incorporação sucessiva de variáveis, até se chegar ao modelo de Hoffman e Ney (2003), irá sempre melhorar a regressão, medindo-se a qualidade dela pelo R2 ajustado. Nota-se o crescimento sistemático do R2 ajustado, mostrando que a literatura fez bem em incorporar todas as suas 19 variáveis. Observa-se, também, que o R2 ajustado cresce ainda mais com a adição do termo para a variável proprietário no modelo de regressão. Na estimativa dos coeficientes das variáveis, foram obtidos resultados inteiramente 


\section{8 - 0 Efeito do Título de Propriedade da Terra na Determinação da Renda Rural}

coerentes com os da literatura: mesmo sinal, mesma grandeza dos números, mas não exatamente os mesmos valores, conforme era de se esperar. Hoffmann e Ney trabalham com uma PNAD rural de 16.221 observações, enquanto aqui se gera uma PNAD deste tipo com 16.548 observações.

Os autores em questão estimam quatro equações de rendimento: o modelo 1 não incorpora as variáveis "posição na ocupação" e área; no modelo 2, incluise a "posição na ocupação"; no modelo 3 inclui-se ambas: "posição na ocupação" e área; o modelo 4 trata escolaridade com 15 variáveis binárias para os coeficientes da regressão para cada ano de estudo.

O objetivo do estudo supracitado é o de mostrar como o coeficiente da regressão para escolaridade é afetado pela incorporação de variáveis que mensuram, de alguma forma, o grau de riqueza do indivíduo, quer pela "posição na ocupação", que está correlacionada com a posse da terra, ou pelo tamanho da área declarada. A preocupação do presente artigo é outra: a de como as próprias estimativas dos autores são afetadas pela inclusão de uma nova variável indicadora do direito de propriedade da terra (não apenas posse). Tomando-se o modelo 3, que inclui área e "posição na ocupação", o propósito desta seção é o de comparar os resultados desse outro estudo com o nosso a respeito dos seguintes aspectos: (1) Os coeficientes das variáveis na regressão. (2) A "renda esperada" para as variáveis binárias (diferença percentual entre os rendimentos estimados na categoria considerada e na categoria tomada como base). (3) A contribuição marginal de cada fator para a soma dos quadrados da regressão.

Fazendo-se a comparação entre os dois trabalhos, observa-se que as discrepâncias são notadas apenas para os coeficientes estimados das variáveis empregador, amarela, log da hora trabalhada e nordeste. Para a variável chave escolaridade, a diferença é quase nula (coeficiente estimado pela regressão de 0,065 nesta estimativa contra 0,060 na literatura), e para a outra variável chave log da área a diferença é mínima (0,157 aqui contra 0,182). Mesmo nos quatro casos mais discrepantes, o sinal do coeficiente é o mesmo nos dois estudos. Por exemplo, na variável empregador, tanto na literatura quanto em nossa estimativa, o coeficiente é positivo e importante.

Mais significativas foram as diferenças para variáveis binárias, entre as rendas esperadas que se estimam e aquelas obtidas pelo outro estudo. As maiores discrepâncias notadas (superando 200\%) ocorreram para as variáveis binárias cor preta, parda e indígena e empregador.

Deixa-se explicitado o presente método de cálculo: para cada variável binária, primeiramente gera-se uma base de dados em que ocorre a categoria tomada como base (a ocorrência em que não se atribui variável binária e que funciona como base de comparação). Estima-se para essas observações a renda 
esperada. Na medida em que a variável de renda em nosso modelo de regressão é o logaritmo da renda, considera-se o algarismo neperiano $e$ elevado ao resultado da renda estimada, que na verdade é o log da renda. Portanto, $\mathrm{e}^{\log y}=\mathrm{y}$. A renda de referência (o log dela) é a renda média calculada na sub-base de dados PNAD em que ocorre apenas a categoria de referência. Assim, por exemplo, para a variável cor, calcula-se a renda média dos brancos (categoria base) na base de dados contendo apenas brancos.

Estima-se, a seguir, a renda para as categorias consideradas que será depois comparada com a respectiva renda da categoria de referência. Em cada caso, calcula-se então a diferença entre uma e outra. Obtém-se o log da renda média, a renda monetária média e a diferença percentual em relação à categoria de base. Compara-se com os resultados correspondentes de Hoffmann e Ney. A renda média dos proprietários é, em 2001, 45,1\% acima da dos não proprietários. Os de domicílio rural ganham 18,9\% menos que os de domicílio urbano (9,6\% a menos em Hoffmann e Ney), os de conta própria ganharam, em 2001, 5,7\% a menos que os empregados (30,9\% a menos na literatura) e os empregadores ganharam $285 \%$ a mais (39\% a mais no estudo de referência).

Em seguida, calcula-se a contribuição marginal de cada uma das variáveis explicativas para a soma de quadrados da regressão. Dividindo-se a soma de quadrados dos resíduos de cada variável pela soma de quadrados da regressão, estima-se a contribuição marginal de cada fator para a soma de quadrados da regressão. Para quase todas as variáveis, utiliza-se a soma dos quadrados da variável do tipo III. Nas variáveis "posição na ocupação" e "log da hora trabalhada", utilizou-se a soma dos quadrados obtida pelo método do tipo I. Tal escolha deu-se porque o tipo I, neste caso, replicava melhor os resultados da literatura. A variável cor capta a contribuição da cor parda, e a variável região, a contribuição de São Paulo. Então, se notam resultados muito próximos ao da literatura exceto para sexo (0,013 aqui contra 0,005 na referência) e log da área $(0,072$ contra 0,102).

\section{Análise comparativa entre sete PNADs}

Nesta seção, estimam-se coeficientes de regressão para todas as variáveis, nas estimativas da renda dos rurais, considerando-se as PNADs de 1992, 1993, 1999, 2001, 2002, 2003 e 2005. Primeiramente, rodam-se as rotinas de programação do SAS que criam novas variáveis e geram as bases de dados da PNAD rural. Há diferenças sutis na seleção de variáveis entre os anos considerados. Para cada base de dados, aplica-se um modelo de regressão acionando rotinas de programação específicas. Nessas regressões, considera- 
se, de início, as mesmas variáveis tratadas por Hoffmann e Ney (2003), sem a inclusão da variável "proprietário". Os coeficientes assim estimados em cada ano aparecem na segunda coluna da Tabela 1. O próximo passo foi incorporar a variável proprietário. Estima-se, então, nova equação de rendimentos para pessoas ocupadas na agricultura, a qual difere pela inclusão da condição do indivíduo se proprietário ou não (terceira coluna).

Tabela 1. Equações de rendimento estimadas para pessoas ocupadas na agricultura brasileira. Coeficientes de regressão com e sem a incorporação da variável "proprietário". PNAD: 1992, 1993, 1999, 2001, 2002, 2003 e 2005. Coeficientes apresentados para escolaridade, conta própria, empregador, log da área e proprietário

\begin{tabular}{|c|c|c|c|}
\hline Variável & Coeficientes & $\begin{array}{c}\text { Coeficientes } \\
\text { com a variável } \\
\text { proprietário }\end{array}$ & $\begin{array}{c}\text { Variação nos } \\
\text { coeficientes com } \\
\text { a variável } \\
\text { proprietário }\end{array}$ \\
\hline \multicolumn{4}{|l|}{ PNAD 1992} \\
\hline escolaridade & 0,0689 & 0,0677 & $-0,0012$ \\
\hline conta própria & $-0,1190$ & $-0,2342$ & $-0,1152$ \\
\hline empregador & 0,7101 & 0,5625 & $-0,1475$ \\
\hline log da área & 0,1175 & 0,1059 & $-0,0116$ \\
\hline proprietário & & 0,2455 & \\
\hline observações & 17.146 & & \\
\hline $\mathrm{R} 2$ & 0,3846 & 0,3902 & 0,0056 \\
\hline R2 ajustado & 0,3846 & 0,3902 & 0,0056 \\
\hline \multicolumn{4}{|l|}{ PNAD 1993} \\
\hline escolaridade & 0,0682 & 0,0651 & $-0,0031$ \\
\hline conta própria & $-0,0414$ & $-0,1967$ & $-0,1554$ \\
\hline empregador & 0,7856 & 0,5856 & $-0,1999$ \\
\hline $\log$ da área & 0,1344 & 0,1122 & $-0,0222$ \\
\hline proprietário & & 0,3656 & \\
\hline observações & 16.637 & & \\
\hline $\mathrm{R} 2$ & 0,4267 & 0,4379 & 0,0112 \\
\hline R2 ajustado & 0,4267 & 0,4379 & 0,0112 \\
\hline
\end{tabular}




\begin{tabular}{|c|c|c|c|}
\hline \multicolumn{4}{|l|}{ PNAD 1999} \\
\hline escolaridade & 0,0611 & 0,0593 & $-0,0017$ \\
\hline conta própria & $-0,2124$ & $-0,3158$ & $-0,1034$ \\
\hline empregador & 0,669 & 0,5534 & $-0,1160$ \\
\hline log da área & 0,1282 & 0,1136 & $-0,0146$ \\
\hline proprietário & & 0,2305 & \\
\hline observações & 16.376 & & \\
\hline $\mathrm{R} 2$ & 0,4205 & 0,4271 & 0,0066 \\
\hline R2 ajustado & 0,4205 & 0,4271 & 0,0066 \\
\hline \multicolumn{4}{|l|}{ PNAD 2001} \\
\hline escolaridade & 0,0645 & 0,0628 & $-0,0017$ \\
\hline conta própria & $-0,3546$ & $-0,4636$ & $-0,1090$ \\
\hline empregador & 0,4720 & 0,3405 & $-0,1315$ \\
\hline $\log$ da área & 0,1571 & 0,1430 & $-0,0140$ \\
\hline proprietário & & 0,2371 & \\
\hline observações & 16.548 & & \\
\hline R2 & 0,3886 & 0,3944 & 0,0058 \\
\hline R2 ajustado & 0,3886 & 0,3944 & 0,0058 \\
\hline \multicolumn{4}{|l|}{ PNAD 2002} \\
\hline escolaridade & 0,0599 & 0,0584 & $-0,0015$ \\
\hline conta própria & $-0,3069$ & $-0,4169$ & $-0,11$ \\
\hline empregador & 0,7871 & 0,6587 & $-0,1284$ \\
\hline $\log$ da área & 0,1324 & 0,1191 & $-0,0133$ \\
\hline proprietário & & 0,2377 & \\
\hline observações & 16.796 & & \\
\hline $\mathrm{R} 2$ & 0,4205 & 0,4279 & 0,0074 \\
\hline R2 ajustado & 0,4205 & 0,4279 & 0,0074 \\
\hline
\end{tabular}


692 - 0 Efeito do Título de Propriedade da Terra na Determinação da Renda Rural

\begin{tabular}{llll}
\hline PNAD 2003 & & & \\
escolaridade & 0,0591 & 0,0574 & $-0,0018$ \\
conta própria & $-0,3070$ & $-0,4160$ & $-0,109$ \\
empregador & 0,6099 & 0,4749 & $-0,1350$ \\
log da área & 0,1263 & 0,1123 & $-0,0141$ \\
proprietário & & 0,2458 & \\
observações & 17.035 & & \\
R2 & 0,414 & 0,4199 & 0,0059 \\
R2 ajustado & 0,414 & 0,4199 & 0,0059 \\
\hline PNAD 2005 & & & \\
escolaridade & 0,0629 & 0,0613 & $-0,0016$ \\
conta própria & $-0,4318$ & $-0,5534$ & $-0,1215$ \\
empregador & 0,4697 & 0,3379 & $-0,1319$ \\
log da área & 0,1333 & 0,1154 & $-0,0179$ \\
proprietário & & 0,2764 & \\
observações & 18.740 & & \\
R2 & 0,4257 & 0,4329 & 0,0072 \\
R2 ajustado & 0,4257 & 0,4329 & 0,0072 \\
\hline
\end{tabular}

Fonte: Cálculos do autor com base em "microdados" das correspondentes PNADs.

Obs.: Todos os coeficientes são significativos a $1 \%$.

A coluna "variação nos coeficientes com a variável proprietário" trata da diferença entre os novos coeficientes com a inclusão desta variável e os coeficientes anteriores. Nota-se que, na grande maioria das variáveis explicativas (incluindo as não mostradas na tabela), os coeficientes estimados ficam menores com a inclusão da nova variável (sinal negativo na última coluna); excetuando-se o intercepto (só em 1992 ele fica menor na regressão com a nova variável). As exceções, em que ocorrem variações positivas nos coeficientes estimados com a inclusão da variável proprietário, ocorrem para o log da hora trabalhada (em todas as PNADs, exceto a de 2005); para algumas etnias, principalmente preto, indígena e pardo (em todos os anos há variações positivas ao menos em uma delas); para região em 1992 e São Paulo em 1999, e para condição de arrimo em 2001. 
Ainda analisando os resultados, vale observar como se modificam os parâmetros gerais da regressão de equações de rendimento quando se inclui a variável que capta a condição de proprietário da terra rural. Primeiramente, cabe destacar que o R2 ajustado aumenta em todas as PNADs consideradas com a inclusão da variável proprietário. Isso mostra que a nova variável melhora a qualidade da estimação ${ }^{7}$. Com base no valor do R2 ajustado, conclui-se que a inclusão da variável de propriedade mostrou-se desejada em todos os casos. Em apenas algumas poucas variáveis a inclusão da variável de propriedade torna mais intenso o efeito delas, medido pelo coeficiente da regressão. Nota-se, entretanto, que apenas a variável log da hora trabalhada sempre apresenta intensificado o seu efeito sobre o logaritmo do rendimento quando se inclui a variável propriedade. Na grande maioria dos casos, o efeito da propriedade é o de diminuir o impacto das variáveis na determinação da renda agrícola, medido pela queda do coeficiente de regressão.

É importante também observar o comportamento dos coeficientes de escolaridade e de área (em logaritmo) quando se inclui a variável de propriedade. Em todos os casos analisados, o coeficiente de área se reduz significativamente com a inclusão da nova variável no modelo de regressão. A redução no coeficiente depende do ano considerado. O coeficiente da regressão para a variável proprietário é sempre positivo: 0,2455 em 1992, 0,3656 em 1993, 0,2305 em 1999, 0,2371 em 2001, 0,2377 em 2002, 0,2458 em 2003 e 0,2764 em 2005. Em todos os casos, ele é superior ao coeficiente do logaritmo da área.

A leitura dos testes t e o valor do coeficiente levam a concluir que a variável propriedade é significativa na formação da renda agrícola. A exclusão desta variável superestima não apenas os coeficientes de escolaridade, mas o próprio coeficiente da variável área. Nota-se, portanto, que as estimativas de Hoffmann e Ney, para 2001, dos coeficientes da área, eram exageradas: 0,181 naquele trabalho contra 0,143 quando se incorpora a variável propriedade no modelo. Isto se deve ao fato de a área correlacionar-se com uma variável omitida que é a propriedade da terra. Nas áreas maiores, cresce a ocorrência de proprietários. Então o efeito que se captou não era apenas um efeito de posse (entendida como medida de riqueza), mas também um efeito dos direitos de propriedade da terra.

Um exercício que também se mostrou esclarecedor consiste em separar a PNAD rural em dois grupos de proprietários e de não proprietários. Para evitar erro de dependência linear entre as variáveis explicativas, eliminou-se em cada grupo a variável de empregador na estimativa da equação de rendimento, restando apenas a variável de conta própria como condição do produtor. Para a

${ }^{6}$ Sobre a teoria da agência, consultar Stephen Ross (1973). 
PNAD de 2001, o modelo gera um R2 de 0,40, sendo que todos os coeficientes das variáveis são estimados de modo significativo (5\% de significância), exceto a variável indígena.

Obteve-se a estimativa de todos os coeficientes das variáveis consideradas no modelo em equações de rendimento estimadas para as PNADs dos sete anos considerados. A Tabela 2 mostra informações para os anos de 1992, 2001 e 2005, exibindo-se os coeficientes estimados nas três variáveis destacadas neste estudo (escolaridade, condição do produtor e log da área). Na segunda coluna, são estimados os coeficientes das variáveis na estimativa para a base de proprietários. A próxima coluna evidencia como os coeficientes se alteram em relação ao modelo básico aplicado a toda a PNAD rural (neste caso, também com a variável de empregador). Quando se considera apenas a PNAD rural de proprietários, alguns coeficientes crescem e outros decrescem em relação ao modelo básico para toda a PNAD rural. Entre outras informações, nota-se que o coeficiente para escolaridade, na nova situação, cai bastante nas PNADs de 1992 (-15,7\%) e 1993 $(-14,5 \%)$, mas aumenta nos demais anos considerados. Ou seja, não se observa uma relação estável ao longo do tempo entre ser proprietário e ter um efeito maior da variável escolaridade na determinação da renda.

Destaca-se também os coeficientes para o "logaritmo da área": o coeficiente estimado na regressão para esse fator explicativo da renda oscila entre 0,107 e 0,157. A tendência geral é de que os coeficientes da área sejam maiores no grupo de proprietários, o que seria de se esperar; contudo, nota-se que, para os anos de 1999, 2003 e 2005, o coeficiente da área é maior no grupo dos proprietários do que no grupo dos não proprietários. Então, é importante a leitura das variações nos coeficientes nessa comparação entre o modelo de regressão para a PNAD rural como um todo e o caso somente com proprietários ou somente para não proprietários. Dificilmente os coeficientes mudariam de modo sistemático. O tamanho da área, ou a escolaridade ou outras das variáveis consideradas nem sempre estão bem correlacionados com o fato de a pessoa ser proprietária, mas os proprietários, em geral, ocupam áreas maiores e tem grau maior de escolaridade. Contudo, isso não implicou em coeficientes maiores na equação de regressão. Nota-se também a quarta coluna da Tabela 2, com os coeficientes para a PNAD rural de não proprietários. Cabe comparar estes resultados com o modelo para proprietários. O intercepto (não mostrado na tabela) sempre cai em todos os anos analisados, mostrando que os não proprietários são mais pobres. Apenas nas PNADs de 1992 e 2001 o coeficiente de área é bem menor para os não proprietários em relação aos proprietários. A área é determinante mesmo entre os não proprietários; ela, de fato, está associada a um efeito de posse, mas não a um efeito de propriedade. 
Já a diferença entre os dois grupos de proprietários e de não proprietários, quanto ao efeito da escolaridade na determinação da renda, flutua muito dependendo da PNAD em questão (Gráfico 1), sendo positiva (coeficiente maior da escolaridade no grupo de não proprietários) apenas no início da série em 1992 e 1993, e tornando-se negativa nas PNADs subsequentes.

Tabela 2. Equações de rendimento estimadas para pessoas ocupadas na agricultura brasileira. Coeficientes de regressão para a PNAD rural de proprietários e de não proprietários. PNAD: 1992, 2001 e 2005

\begin{tabular}{|c|c|c|c|c|}
\hline \multirow[t]{2}{*}{$\begin{array}{l}\text { Variável / R2 / No. } \\
\text { observações }\end{array}$} & \multicolumn{2}{|c|}{$\begin{array}{l}\text { Modelo } 1 \text { - PNAD rural de } \\
\text { proprietários }\end{array}$} & \multicolumn{2}{|c|}{$\begin{array}{l}\text { Modelo } 2 \text { - PNAD rural de não } \\
\text { proprietários }\end{array}$} \\
\hline & Coeficientes & $\begin{array}{l}\text { Variação em } \\
\text { relação ao } \\
\text { modelo para } \\
\text { toda a PNAD } \\
\text { rural }\end{array}$ & Coeficientes & $\begin{array}{l}\text { Variação em } \\
\text { relação ao } \\
\text { modelo } 1\end{array}$ \\
\hline \multicolumn{5}{|l|}{ PNAD 1992} \\
\hline escolaridade & 0,058 & $-15,7 \%$ & 0,079 & $35,7 \%$ \\
\hline conta própria & $-0,740$ & $521,4 \%$ & $-0,243$ & $-67,2 \%$ \\
\hline $\log$ da área & 0,137 & $16,2 \%$ & 0,086 & $-36,7 \%$ \\
\hline R2 & 0,379 & & 0,332 & \\
\hline observações & 4.961 & & 12.185 & \\
\hline \multicolumn{5}{|l|}{ PNAD 2001} \\
\hline escolaridade & 0,067 & $3,2 \%$ & 0,061 & $-7,8 \%$ \\
\hline conta própria & $-0,771$ & $117,3 \%$ & $-0,455$ & $-40,9 \%$ \\
\hline $\log$ da área & 0,157 & $0,2 \%$ & 0,118 & $-25,1 \%$ \\
\hline $\mathrm{R} 2$ & 0,402 & & 0,372 & \\
\hline observações & 5.201 & & 11.347 & \\
\hline \multicolumn{5}{|l|}{ PNAD 2005} \\
\hline escolaridade & 0,074 & $18,4 \%$ & 0,054 & $-27,8 \%$ \\
\hline conta própria & $-0,845$ & $95,7 \%$ & $-0,568$ & $-32,8 \%$ \\
\hline $\log$ da área & 0,114 & $-14,7 \%$ & 0,118 & $3,7 \%$ \\
\hline $\mathrm{R} 2$ & 0,423 & & 0,412 & \\
\hline observações & 5.927 & & 12.813 & \\
\hline
\end{tabular}

Fonte: Cálculos do autor com base em "microdados" das correspondentes PNADs.

Obs.: Todos os coeficientes são significativos a $5 \%$. 
Em alguns pouquíssimos casos, os coeficientes não foram significativos. A tabela anterior não indica essas ocorrências. Note que o parâmetro R2 da regressão sempre piora no caso de não proprietários.

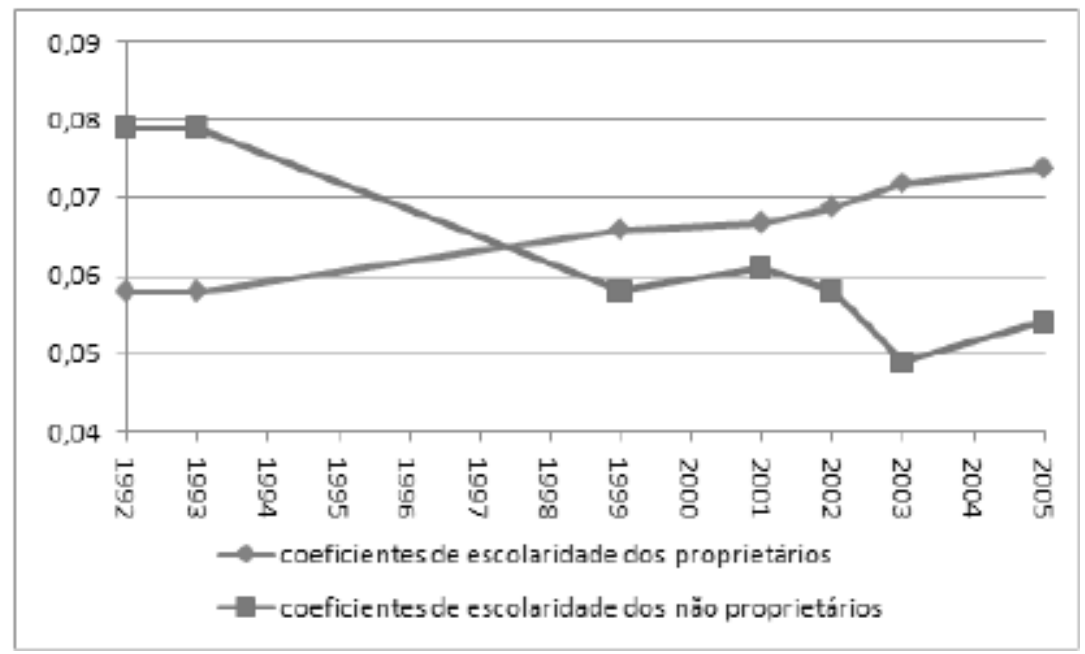

Gráfico 1. Evolução dos coeficientes da variável "escolaridade". Grupo de pessoas ocupadas na agricultura proprietárias e não proprietárias. PNAD rural: 1992, 1993, 1999, 2001, 2002, 2003 e 2005

Fonte: PNADs. Cálculos do autor.

Por fim, chama-se a atenção para a distribuição da amostra entre proprietários e não proprietários. O número de observações no grupo de não proprietários oscila entre pouco mais de 11 mil e quase 13 mil pessoas; o grupo dos não proprietários é de cerca de 5 mil observações (quase 6 mil em 2005). Portanto, há bem mais não proprietários do que proprietários. Os proprietários representam menos de $32 \%$ da amostra. O número de proprietários cresceu significativamente entre as PNADs de 1993 e 1999 e depois se estabilizou no novo patamar. O crescimento do número relativo de proprietários na amostra, entre as PNADs de 1992 e 2005, pode estar relacionado com o início de uma onda importante de reforma agrária no País que se iniciou a partir de 1995. Isso refletiu na composição da PNAD rural, embora o efeito seja tímido, pois a participação dos grupos não flutuou mais do que 3\% entre 1992 e 2005.

Cabe retomar a discussão anterior sobre o comportamento das variáveis escolaridade e área (logaritmo da área) na determinação da renda agrícola 
quando se comparam os dois grupos considerados. O Gráfico 1 permite a visualização completa do que ocorreu com o coeficiente de escolaridade nesses grupos. Nota-se que a tendência para o grupo de proprietários foi a de elevação contínua do coeficiente. Já no grupo dos não proprietários, a tendência do coeficiente estimado para escolaridade é decrescente, com ligeira estabilidade entre 1999 e 2002. É mesmo de se esperar que os coeficientes sejam mais expressivos no grupo dos proprietários: por serem mais ricos, os proprietários, em média, já atingiram um patamar a partir do qual a educação passa a importar mais na geração da renda, ao contrário do outro grupo em que muito de seus membros estão numa condição na qual déficit de saúde etc. são mais críticos do que a falta de instrução.

O Gráfico 2 mostra a evolução dos coeficientes para a variável log da área para as PNADs consideradas. Chama a atenção o fato de o coeficiente estimado para o logaritmo da área ser sistematicamente superior no grupo dos proprietários até 2002. Este resultado ressalta diretamente um aspecto do trabalho de Hoffmann e Ney (2003): a estimativa para o coeficiente de área que eles obtiveram superestimou a contribuição desta variável na determinação da renda agrícola, pois consideraram a PNAD rural com proprietários e não proprietários. Se tivessem considerado apenas a PNAD rural para não proprietários, o valor do coeficiente dessa variável teria sido consideravelmente menor. A diferença entre as trajetórias deste coeficiente entre proprietários (sempre maior até 2002) e não proprietários é particularmente maior na PNAD analisada pelos autores, que foi a de 2001. A explicação do viés evidente é a de que a variável área (ou o log dela) está correlacionada com a variável omitida "proprietário", de forma que o coeficiente da primeira fica inflado pelo efeito embutido da condição de ser proprietário, que, assim como a área, contribui para ganhos de rendimentos agrícolas: a primeira pelos efeitos econômicos dos direitos de propriedade e a segunda variável, como apontaram os autores, como efeito da posse da terra, enquanto medida de riqueza. Note, ademais, que para os dois últimos anos analisados, a relação inverte-se e o coeficiente da área para não proprietário passa a ser maior. 


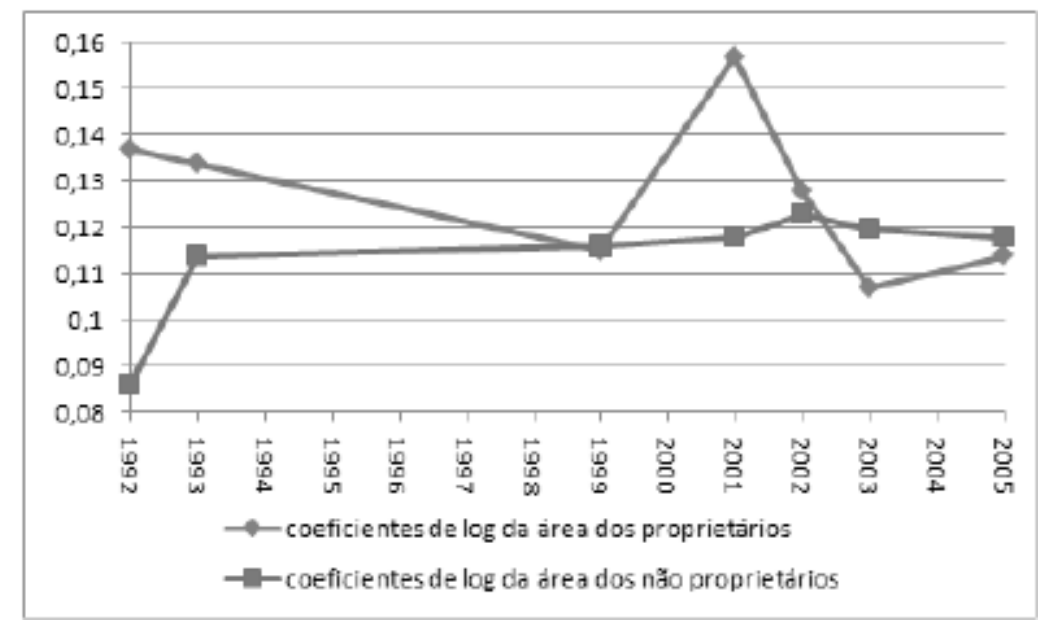

Gráfico 2. Evolução dos coeficientes da variável "log da área" (logaritmo da área do estabelecimento). Grupo de pessoas ocupadas na agricultura proprietárias e não proprietárias. PNAD rural: 1992, 1993, 1999, 2001, 2002, 2003 e 2005

Fonte: PNADs. Cálculos do autor.

\section{Cálculo da renda agrícola esperada e tamanho das categorias}

Nesta seção, foram calculadas as rendas médias para as PNADs de 1992 e 2005 (para 2001, foram obtidas na seção (5)), selecionando, portanto, as duas PNADs nos extremos opostos da série aqui analisada. Pretende-se, com isso, acompanhar a evolução das médias neste intervalo de 13 anos, a fim de compreender as transformações no perfil dos rendimentos das várias categorias analisadas. O método utilizado no cálculo das diferenças na renda média é o mesmo já especificado na seção (5). A Tabela 3 mostra os resultados.

Além da diferença para os grupos de proprietários e não proprietários, as informações mostram as diferenças na renda média entre os de domicílio rural e urbano, bem como nas três condições do produtor consideradas. Calcula-se para todas as variáveis, mas só se exibem os números para essas três categorias. 
Tabela 3. Renda esperada das variáveis binárias na PNAD de 1992 e 2005. Diferença percentual entre os rendimentos estimados da categoria considerada e da categoria tomada como base

\begin{tabular}{|c|c|c|c|c|}
\hline & $\begin{array}{l}\text { Número de } \\
\text { observações }\end{array}$ & $\begin{array}{c}\text { Log da renda } \\
\text { média }\end{array}$ & $\begin{array}{l}\text { Renda monetária } \\
\text { média (na moeda } \\
\text { nacional) }\end{array}$ & $\begin{array}{c}\text { Diferença } \\
\text { percentual em } \\
\text { relação à } \\
\text { categoria de } \\
\text { base }\end{array}$ \\
\hline \multicolumn{5}{|l|}{1992} \\
\hline não propriet. & 12.185 & 12,86 & 382.779 & $=$ \\
\hline proprietários & 4.961 & 13,38 & 644.550 & $68,4 \%$ \\
\hline não rurais & 5.519 & 13,15 & 513.620 & $=$ \\
\hline rurais & 11.627 & 12,94 & 415.811 & $-19,0 \%$ \\
\hline empregados & 9.717 & 12,85 & 382.471 & \\
\hline conta própria & 6.710 & 13,01 & 448.402 & $17,2 \%$ \\
\hline empregadores & 1.012 & 14,41 & 1.819 .497 & $305,8 \%$ \\
\hline \multicolumn{5}{|l|}{2005} \\
\hline não propriet. & 12.813 & 5,49 & 243 & $=$ \\
\hline proprietários & 5.927 & 5,80 & 329 & $35,7 \%$ \\
\hline não rurais & 6.053 & 5,69 & 297 & $=$ \\
\hline rurais & 12.687 & 5,54 & 254 & $-14,4 \%$ \\
\hline empregados & 9.999 & 5,59 & 268 & \\
\hline conta própria & 7.683 & 5,43 & 154 & $-42,5 \%$ \\
\hline empregadores & 989 & 6,88 & 629 & $135,1 \%$ \\
\hline
\end{tabular}

Fonte: PNADs. Cálculos do autor.

A tabela anterior e os cálculos não mostrados evidenciam importantes resultados:

(1) Os proprietários, em 1992, auferiam 68,4\% mais renda que os não proprietários. Em 2005, só ganham 35,7\% a mais - o que evidencia o fato de a reforma agrária ter, no período, incorporado proprietários pobres no primeiro grupo. 
(2) Os rurais, ou seja, os de domicílio rural, são mais pobres que os não rurais de domicílio urbano. Em termos de diferença de renda, eram 19\% mais pobres em 1992 e, mais recentemente em 2005, são 14,4\% mais pobres.

(3) A região Nordeste concentra os agricultores mais pobres. A diferença a favor das demais regiões vem aumentando para as regiões Norte (de 61,4\% para 70,6\%) e Centro-Oeste (de $114 \%$ para $119,5 \%$ ); mas vem diminuindo para as demais regiões: Sudeste (de 56,6\% para 53,1\%), São Paulo (de 157,2\% para 131,5\%) e Sul (de 113,9\% para $101,6 \%)$.

(4) Os arrimos de família são mais ricos que os não arrimos, mas a diferença caiu de 66\% em 1992 para 41,1\% em 2005.

(5) As mulheres rurais ganham menos que os homens. A diferença caiu um pouco: de 41,7\% a menos para as mulheres para 38,5\% em 2005.

(6) Para a categoria cor, em relação aos brancos, os pretos, pardos e indígenas eram cerca de $40 \%$ mais pobres em 1992, e essa diferença caiu para cerca de 30\% em 2005. Os indígenas estão em situação ainda pior que os demais. Já os amarelos (orientais) eram, em média, $227 \%$ mais ricos que os brancos em 1992. Essa vantagem caiu bastante no período: é de $86 \%$ em 2005.

(7) Os de conta própria ganham $42 \%$ a menos do que os empregados em 2005, mas ganhavam 17,2\% a mais em 1992. Os empregadores ganhavam 306\% a mais em relação ao valor da renda dos empregados, mas essa vantagem caiu para 135\% em 2005.

Os resultados da renda esperada para a PNAD de 2005, em relação à PNAD de 1992, mostram que, em relação aos rendimentos agrícolas, vem ocorrendo uma mudança nas diferenças regionais, com vantagem para Norte e Centro-Oeste e desvantagem para Sul e Sudeste (incluindo São Paulo); visto que apenas no primeiro caso a diferença de rendimentos em relação aos nordestinos crescera. Constata-se também uma diminuição nos diferenciais de renda entre cor e entre gênero. Os empregadores diminuíram a vantagem sobre os empregados, e os de conta própria também pioraram e estão agora abaixo da renda média dos empregados. A diferença de renda esperada entre arrimos e não arrimos de família diminuiu; reduziu a desvantagem dos residentes em domicílio rural em relação aos de domicílio urbano e a diferença entre proprietários e não proprietários é menor. 


\section{Avaliação das regressões, cálculo de médias e a contribuição marginal dos fatores}

Mostra-se, nesta seção, o que dizem os resultados observados com o tratamento de dados das PNADs e se o resultado condiz com as expectativas criadas pela exposição teórica. Três conclusões são esperadas:

(1) Como acredita-se que os direitos de propriedade importam na formação dos rendimentos agrícolas, espera-se que a incorporação da variável "proprietário" melhore a regressão (crescimento do R2 ajustado).

(2) Que, sob o impacto da reforma agrária acentuada desde 1995, as diferenças nas médias de rendimento entre os grupos de proprietários e de não proprietários estejam diminuindo.

(3) Que os coeficientes de regressão da variável "proprietário" decresçam ao longo dos anos, sendo menor nas PNADs mais recentes, enquanto indicativo da expansão de alcance do programa de reforma agrária.

De fato, a incorporação da variável representativa dos direitos de propriedade melhorou a regressão medida pelo crescimento do $\mathrm{R} 2$ ajustado. As diferenças percentuais nesse parâmetro de regressão são sempre maiores que 1,4\% em relação ao modelo sem a variável proprietário. Em 1993, o diferencial chega a mais de 2,6\%, e a menor distância ocorre em 2003. Em 2001, ano em que recaem os estudos de Hoffmann e Ney (2003), a incorporação da variável proprietário melhorou o R2 ajustado em quase 1,5\%. Esses resultados evidenciam a relevância de se considerar uma proxy binária específica indicadora de propriedade: melhoram as estimativas da renda esperada em relação ao modelo que considera apenas indicadores de posse da terra (natureza da ocupação e área do estabelecimento).

Em relação à segunda conclusão esperada, a de que as diferenças nas médias de rendimento entre os grupos de proprietários e de não proprietários estivessem diminuindo, tal resultado também foi alcançado observando-se as informações oriundas das PNADs. A Tabela 3 mostra as diferenças percentuais, para as PNADs de 1992 e 2005, entre os rendimentos estimados de proprietários e de não proprietários: a diferença entre rendimentos da categoria de proprietários e da categoria de não proprietários tomada como base, foi de 68,4\% em 1992. O resultado para a PNAD de 2001 tinha sido de 45,1\%, e para a PNAD de 2005, ficou em 35,7\% de vantagem na renda dos proprietários. Portanto, a renda esperada para proprietários continua bastante superior a dos não proprietários, porém, as diferenças, conforme esperado, diminuíram entre 
1992 (período anterior à forte expansão da reforma agrária), 2001 e o ano de 2005 (já sob o impacto dos esforços cumulativos de assentamentos de milhares de famílias rurais).

Não se confirmou a expectativa de que os coeficientes de regressão da variável "proprietário" (para toda a PNAD rural) diminuíssem ao longo dos anos: indicativo do alcance do programa de reforma agrária. De fato, o ano de 1999, já sob o efeito do surto de reforma agrária, apresenta um coeficiente de regressão para a variável em questão menor do que o de 1992 (Gráfico 3). No entanto, desse ano em diante, o referido coeficiente é estável e chega mesmo a crescer entre 2003 e 2005. O log da área, ao longo das PNADs consideradas, cresce significativamente: do patamar de 0,1 em 1992 para o patamar de 0,15 em 2001, mas depois volta ao patamar inicial. Esses resultados comparativos parecem traduzir o pouco efeito da reforma agrária no perfil de proprietários: as mudanças na estrutura de direitos de propriedade no campo não puderam ser captadas nos coeficientes das variáveis explicativas do modelo de regressão.

Talvez outros fatores estejam condicionando a determinação do coeficiente das variáveis área e proprietário (além da limitação metodológica nas comparações entre PNADs de diferentes anos). É difícil captar o efeito da reforma agrária nas estatísticas das PNADs, em que pese a literatura em Economia Neoinstitucional argumentar a favor do impacto econômico dos direitos de propriedade. A PNAD de 2001 apresentou o maior coeficiente para a variável "log da área". Ele foi menor tanto nas PNADs anteriores (1992, 1993 e 1999) quanto nas PNADs subsequentes de 2002, 2003 e 2005. É difícil precisar o que tenha provocado oscilações nesses coeficientes, além das discrepâncias metodológicas e amostrais entre as PNADs. Se a variável área é entendida como medida de posse da terra e de riqueza, o efeito posse (riqueza) parece ter sido mais forte justamente em 2001, ano analisado por Hoffmann e Ney (2003). Suspeita-se, portanto, que as conclusões daquele estudo ficam enfraquecidas para outros anos. Por fim, nota-se o ligeiro declínio do coeficiente de escolaridade nas equações de regressão para estimativa da renda agrícola. De fato, ao longo das PNADs analisadas, a variável escolaridade vem se tornando um pouco menos importante na estimação da renda esperada. 


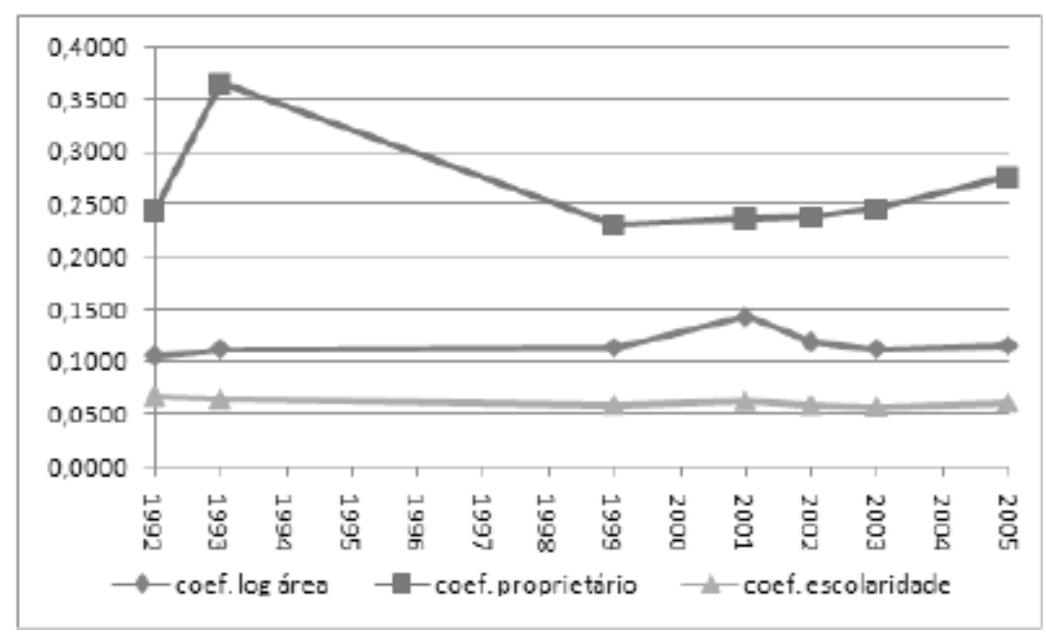

Gráfico 3. Evolução dos coeficientes de logaritmo da área, proprietário e escolaridade nas equações de rendimento estimadas com inclusão da variável "proprietário". PNAD rural: 1992, 1993, 1999, 2001, 2002, 2003 e 2005

Fonte:PNADs. Cálculos do autor.

A Tabela 4 registra a contribuição marginal de cada fator para a soma de quadrados de regressão; em outras palavras, a contribuição de cada qual para a explicação das variações do logaritmo da renda de todos os trabalhos das pessoas com atividade principal na agricultura. Isto permite avaliar a importância relativa de cada variável explicativa no modelo de regressão. Fezse esta estimativa para todas as PNADs consideradas neste ensaio, mas se mostram os resultados para cinco variáveis e em dois anos, inicial e final, da série. Compara-se os resultados com os de Hoffmann e Ney (2003) para a PNAD de 2001 (modelo incluindo apenas a posição na ocupação e modelo incluindo posição na ocupação e área): eles foram muito próximos aos da literatura; as discrepâncias foram significativas apenas para as variáveis sexo e posição na ocupação (para o modelo com área), e sexo e log da hora trabalhada no modelo sem inclusão de área ${ }^{8}$.

Na segunda coluna estão os coeficientes da contribuição marginal em porcentagem. Na terceira coluna, "roda-se" o modelo de regressão sem a variável

\footnotetext{
7 Veja a respeito: Maddala (p.124-127).

8 Em dois casos, a soma dos quadrados do Tipo I foi utilizada para maior acordo de resultados com os da literatura.
} 
704 - 0 Efeito do Título de Propriedade da Terra na Determinação da Renda Rural

área. Na terceira coluna, mantém-se a área e acrescenta-se a variável de propriedade. Conforme já observado na literatura, nota-se que a inclusão da variável área reduz a contribuição marginal da grande maioria dos outros determinantes da renda agrícola. O mesmo fenômeno observa-se agora com a introdução da variável de propriedade no modelo. Nota-se que as estimativas foram feitas rodando o comando SAS GLM e considerando a soma dos quadrados do resíduo das variáveis na convenção do Tipo III.

Tabela 4. Contribuição marginal de cada fator do modelo para a soma de quadrados da regressão. PNAD 1992 e 2005

\begin{tabular}{lccc}
\hline $\begin{array}{l}\text { PNAD 1992 } \\
\text { Variável }\end{array}$ & Coeficientes & Sem a variável área & $\begin{array}{l}\text { Com a variável } \\
\text { propriedade }\end{array}$ \\
\hline escolaridade & $6,39 \%$ & $8,00 \%$ & $6,07 \%$ \\
conta própria & $0,40 \%$ & $0,61 \%$ & $1,20 \%$ \\
empregador & $4,09 \%$ & $14,44 \%$ & $2,25 \%$ \\
log da área & $4,11 \%$ & & $3,21 \%$ \\
proprietário & & & $1,44 \%$ \\
\hline PNAD 2005 & Coeficientes & Sem a variável área & propriedade \\
Variável & $7,42 \%$ & $9,17 \%$ & $6,91 \%$ \\
\hline escolaridade & $4,77 \%$ & $1,36 \%$ & $6,29 \%$ \\
conta própr. & $1,53 \%$ & $8,59 \%$ & $0,73 \%$ \\
empregador & $4,46 \%$ & & $3,14 \%$ \\
log da área & & & $1,67 \%$ \\
proprietário & & & \\
\hline
\end{tabular}

Fonte: PNADs. Cálculos do autor.

Obs.: Todos os coeficientes são significativos a 5\%. 


\section{Conclusão}

Esse ensaio evidencia a importância da Economia Neoinstitucional e de como ela dá conta de explicar, dentro de um bom arcabouço analítico, o efeito dos direitos de propriedade no desempenho econômico. Com o domínio desta literatura, obteve-se motivação para se investigar, na base empírica, alguma relação do processo de reforma agrária com os dados subsequentes das PNADs em diferentes anos. Os direitos de propriedade importam, pois, no ambiente econômico real vicejam custos de transação. A presença de tais custos, associados à informação imperfeita, faz com que o desempenho econômico dependa da estrutura institucional dos direitos de propriedade.

O objetivo do ensaio foi o de tentar captar algum efeito do crescente número de assentamentos agrários no perfil das PNADs. Algo, de fato, foi encontrado: vê-se, por exemplo, que os proprietários são mais ricos que os não proprietários; que a maioria dos empregadores é de proprietários. O processo de reforma agrária pôde ser captado pelo aumento do número relativo de proprietários entre 1992 e 2005; porém, nota-se que essa mudança de composição é ainda bastante tímida (inferior a 3\%). Outro dado que comprova o impacto da reforma agrária é a diminuição nas diferenças de renda agrícola entre os grupos de proprietários e de não proprietários. Conforme argumentado, a inclusão de proprietários pobres beneficiados pela reforma agrária rebaixa a média do grupo de proprietários e aumenta a média dos não proprietários, reduzindo as diferenças.

Quanto à análise do impacto produtivo dos direitos de propriedade, demonstra-se que a variável direitos de propriedade é significativa no modelo de regressão que estima a renda esperada do agricultor. Em parte porque os proprietários são os mais ricos, mas em parte devido ao fato de os direitos de propriedade afetarem diretamente o potencial de ganho dos agricultores. Isso porque o efeito riqueza já tinha sido captado pela inclusão das variáveis "condição do produtor" e área, conforme aceito na literatura, de forma que a variável proprietário explica outro tipo de efeito além do efeito riqueza.

Outro aspecto é o que ocorreu com o coeficiente estimado da variável proprietário ao longo da série temporal com diferentes PNADs. Na parte teórica, argumenta-se que se esperaria que esse coeficiente reduzisse ao longo dos anos, porque os direitos de propriedade são menos determinantes da renda quando se adicionam agricultores mais pobres no grupo de proprietários, pois se espera que tais direitos captem também efeitos de riqueza. Mas se existe, na prática, um efeito que não é o de riqueza, associado à variável proprietário, 
um efeito intrínseco aos direitos de propriedade, pode ser então que o coeficiente estimado, sob o impacto dos novos assentados, não esteja, de fato, caindo ao longo das PNADs. Nota-se que, embora o coeficiente estimado para proprietário tenha decaído de 1993 a 1999, ele conhece uma recuperação entre esse ano e o fim da série em 2005, mostrando que a variável não capta apenas um efeito riqueza, mas um efeito inerente aos direitos de propriedade, conforme apresentado na parte teórica da pesquisa.

\section{Referências Bibliográficas}

Alchian, Arme. A., "Some Economics of property Rights". In: Il Político, 30,4, 1965.

Anderson, Terry L., Peter J. Hill, "Privatizing the Commons: An Improvement?", Southern Economic Journal, 50, no.2, October, p. 438-450, 1983).

Calabresi, G. "Some Thoughts on Risk Distribution and the Law of Torts." Tale Law Journal, 70 (No. 4, March): 499-553, 1961

Cheung, Steven N. S., "The structure of a Contract and the Theory of a Nonexclusive Resource." Journal of Law and Economics, 13, abril, p. 49-70, 1970.

CoAse, Ronald H., "The Nature of the Firm", Economica, 4, November, p. 386405, 1937.

Demsetz, H. "The Exchange and Enforcement of Property Rights." Journal of Law and Economics, 3, October, p. 1-47, 1964.

EgGERTsson, Thráinn, Economic Behavior and Institutions, Cambridge U. P., Cambridge, 1999.

Hoffman, Rodolfo, Ney, M. G., "Desigualdade de Renda na Agricultura: o efeito da posse da terra", Economia, 4 (No. 1), janeiro a junho, Niterói (RJ), 2003.

Jensen, Michael C., Meckling, W. H., "Rights and Production Functions: An Application to Labor-Managed Firms and Codetermination." Journal of Business 52 (No. 4): 469-506, 1979. 
MaddaLA, G. S., Econometrics, McGraw-Hill, International Editions, Economic Series, 1998.

Pejovich, Steve, "Karl Marx, Property Rights School and the Process of Social Change." Kyklos, 35, no. 3, p. 383-397, 1982.

Ross, Stephen, "The Economic Theory of Agency: The Principal's Problem." American Economic Review 62, May: 134:139, 1973. 